Article

\title{
Appropriation of Experimental Psychology by Two Jesuit Authors in the First Decades of the Twentieth Century
}

\author{
Marina Massimi* \\ orcid.org/0000-0001-9103-9960
}

Universidade de São Paulo, Ribeirão Preto, SP, Brasil

\begin{abstract}
This historical study analyzes the mode of appropriation of experimental psychology by two authors of the Society of Jesus - J. Fröbes and J. Lindworsky - in the first decades of the twentieth century. The two researchers wrote several works about psychological science, its objects and methods. Some of these texts are textbooks, aimed at the diffusion of the area, including in the context of the Society. Through an analysis of these texts, a clear opening for new methods of knowledge provided by experimental science can be seen, as well as effort to preserve and emphasize the importance of concepts from traditional philosophical psychology. Thus, the two Jesuit authors sought to verify the relevance of aspects of traditional doctrines through new experimental methods and to highlight the relevance to experimental psychology, psychic processes especially significant from the point of view of the Jesuit anthropology. They therefore sought to reconcile ancient and modern aspects, as a mode of appropriation present in the intellectual universe of the Society of Jesus since its founding.
\end{abstract}

Keywords: Joseph Fröbes, Johannes Lindworsky, Jesuits and experimental psychology.

\section{Apropriações da Psicologia Experimental por Dois Autores Jesuítas nas Primeiras Décadas do Século XX}

\section{Resumo}

Esta pesquisa histórica analisa a modalidade de apropriação da psicologia experimental por dois autores da Companhia de Jesus - J. Fröbes e J. Lindworsky - nas primeiras décadas do século XX. Os dois pesquisadores escreveram várias obras sobre a ciência psicológica, seus objetos e métodos. Algumas desses textos são manuais didáticos, voltados para a difusão da área, inclusive no âmbito da Companhia. Através de uma análise dos referidos textos, observa-se uma evidente abertura para os novos métodos de conhecimento proporcionados pela ciência experimental; e, ao mesmo tempo, o esforço de preservar e assinalar a importância de conceitos derivados da psicologia filosófica tradicional. Desse modo, os dois autores jesuítas procuravam verificar a pertinência de aspetos das doutrinas tradicionais através dos novos métodos experimentais; bem como assinalar a relevância para a psicologia experimental, de processos psíquicos especialmente significativos do ponto de vista da antropologia jesuítica. Busca-se

* Mailing address: Universidade de São Paulo, Departamento de Psicologia, Rua Américo Brasiliense, 1340/111, Ribeirão Preto, SP, Brazil 14050-010. Phone: 0163941-3668. E-mail: mmassimi3@yahoo.com Support: Conselho Nacional de Desenvolvimento Científico e Tecnológico (CNPq). 
assim compatibilizar aspectos antigos e modernos, conforme uma modalidade de apropriação presente no universo intelectual da Companhia de Jesus, desde sua fundação.

Palavras-chaves: Josef Fröbes, Johannes Lindworsky, jesuítas e psicologia experimental.

\section{Apropiación de la Psicología Experimental por Dos Autores Jesuitas en las Primeras Décadas del Siglo XX}

\section{Resumen}

Esta investigación histórica analiza el modo de apropiación de la psicología experimental por dos autores de la Compañía de Jesús - Fröbes J. y J. Lindworsky - en las primeras décadas del siglo XX. Los dos investigadores escribieron varias obras en la ciencia psicológica, sus objetos y métodos. Algunos de estos textos son libros de texto, destinado a la difusión de la psicologia experimental, también en la Compañia. A través de un análisis de estos textos, es evidente una clara apertura a nuevos métodos de conocimiento aportado por la ciencia experimental; y, al mismo tiempo, el esfuerzo para preservar y mostrar la importância de los conceptos de la psicología filosófica tradicional. De este modo, los dos autores jesuitas trataron de comprobar la relevancia de los aspectos de las doctrinas tradicionales a través de nuevos métodos experimentales; y señalar la relevancia de la psicología experimental para el estúdio de los procesos psíquicos especialmente significativos desde el punto de vista de la antropología jesuita. Buscando así hacer compatibles aspectos antiguos y modernos, de acuerdo com la forma de apropiación en el universo intelectual de la Compañía de Jesús desde su fundación.

Palabras clave: Josef Fröbes, Johannes Lindworsky, Jesuitas y la psicología experimental.

The category of appropriation proposed by R. Chartier focuses on the historical reconstruction of the "uses and interpretations" of concepts and theories, in order to highlight "the conditions and processes that underpin the operations of production of meaning" performed in the reception of the texts that transmit these concepts and theories (1991, p. 180). Therefore, emphasis is placed on the "plurality of employments and comprehensions" of the knowledge received and transmitted, and on the "creative - even regulated - freedom of the agents" (1991, p. 180).

In this text we deal with agents within a religious community, the Society of Jesus, who played an important cultural role in the modern world (Giard, 1995). The objective is to highlight the mode of appropriation of theories and practices of experimental psychology by these agents, in a historical period that we will see was significant for the history of the community to which they belonged: the end of the nineteenth century and the first decades of the twentieth century. We will carry out the proposed objective, analyzing the contribution of two very sig- nificant figures of this process in Europe: Joseph Fröbes and Johannes Lindworsky.

\section{The Mode of Appropriation of Knowledge for the Society of Jesus}

The Society of Jesus, dissolved in the eighteenth century, was reconstituted in 1814 , with the nineteenth century being dedicated to the reconstruction of the Society along the lines of its original charism, although it was sought to adapt it to the demands of the contemporary world (Colombo \& Massimi, 2014). One of the aspects of this adaptation effort is represented by the insertion of the Jesuits into the intellectual and, particularly, scientific environments. From their origins in the sixteenth century, the Jesuits were active in the world of science (Chinchilla \& Romano, 2008; Romano, 1999, 2012). Thus, especially from the end of the nineteenth century, several of them became interested and dedicated themselves to the sciences and to their teaching in the educational institutes of the Order. For example, the consolidation effort of these educa- 
tional institutions led to the creation of the Gregorian University, in Rome, originally part of the Roman College founded by Ignatius of Loyola in 1551 , which began to function in the year 1873 , becoming a complete organization as the center of university education in 1930 . The institution had been planned to be the center of Jesuit thought in the twentieth century, internationally, and attended by students (Jesuit and non-Jesuit) from all over the world (Gibert, 2006).

In the scientific domain, one of the areas that aroused great interest among the Jesuits was that of the sciences of subjectivity: in fact, since its foundation, the Society of Jesus was attentive to the dimension of the inner experience, including it in the formation proposal of its members, As outlined in Ignatius of Loyola's Spiritual Exercises (Massimi, 2016). Therefore, in the midnineteenth century and in the first decades of the twentieth century, an increase in Psychology could be seen in the Western world, especially in Experimental Psychology, with the reconstituted Society demonstrating an intense interest in this.

The cultural tradition of the Society, from its inception, sought to establish links between tradition and the contemporary moment (Massimi, 2016). This cultural position is inscribed in the Jesuits' own social and religious identity: the Society was created in the sixteenth century, in the historical context of Humanism, specifically at the University of Paris where the founder, Ignatius of Loyola, studied and created a community of students and teachers, who constituted its first nucleus. Paris, an important driving center of scholastic or Thomist philosophy, since the Middle Ages, was also imbued with the humanistic ideals in the sixteenth century. For this reason, the study of Thomas in the light of humanist and renaissance authors characterized the Jesuit formation from then (Caeiro, 1982).

The compatibility between traditional knowledge and modern knowledge was made following the criterion of accommodation, derived from Roman rhetorical art and employed within the scope of the Society, in a broad way, aiming to foster dialogue with the interlocutor and with the context, for the best accomplishment of the missionary goals (Massimi \& Frei- tas, 2007). On the intellectual level, this implied the appropriation of the philosophical tradition of the past, in the light of the influences and significant cultural changes of the contemporary period. In the sixteenth century, for example, the authors of the Conimbricense manuals elaborated by the Jesuits for teaching at the Coimbra school, carried out a re-reading of Aristotle in the light of Thomas Aquinas, however, being receptive to a wide range of influences, some from the earlier philosophical tradition, others characteristic of the intellectual context of Humanism and the Renaissance, influences of a more properly philosophical nature, but also from medical or other areas of "natural philosophy". (Massimi, 2016, p. 173)

\section{Joseph Fröbes and the Commitment in Vetera Cum Novis Coniungere}

At the beginning of the twentieth century, the impasse between tradition and renewal is evident in the reading of the texts prepared by authors of the Society who dedicated themselves to the study of psychology. The manuscript of the German Jesuit Fr. Joseph Fröbes (1866-1947) Sensitive Psychology is emblematic of this. Written in Valkenburg in 1911, this document can be found in the Historical Archive of the Society of Jesus (ARSI) in Rome (ARSI: OPP. NN. 1028).

Before the writing of this work, Fröbes dedicated himself to didactic activity, initially in the field of sciences, as he taught mathematics and physics. Between 1902 and 1904, he studied Psychology at the Universities of Gottingen and Leipzig, under the direction of W. Wundt, learning methods of Experimental Psychology from him. (Frielingsdorf, 2001)

The manuscript found in the Archives was written in Latin, according to the tradition of the Catholic teaching institutions of the time, and presented to the Ignatius Kolleg in Valkenburg (Fröbes, 1911), where the author had taken the philosophical course between 1895 and 1898 and subsequently taught until 1936. In the preface, Fröbes outlines the existence of two areas of 
Psychology: Speculative or Scholastic Psychology and Empirical or Experimental Psychology. He states that they should reciprocally confront each other, just as natural philosophy and the natural sciences do. However, Fröbes says that given the contemporary situation of separation between empirical and speculative sciences, it would be impossible to approach the two areas in a single treatise. Therefore, in the proposed text, he set out to provide a clear view of the empirical sciences so that some philosophical questions could be correctly resolved. He believed that the progress of the empirical sciences could solve "aspects concerning the sensitive life" rather than questions about fundamental truths (such as spirituality of the soul, freedom of will, etc.), which had been deduced by philosophers from already known facts. Similarly, he said, "the natural sciences cooperated to solve questions of natural philosophy" (Fröbes, 1911, p. 4). He declared, therefore, that in approaching the theme of sensory life, "a healthy peripatetic philosophy" will follow (Fröbes, 1911), where, as carried out by Aristotle, ancient and new knowledge would be summarized and discussed, "so that adherence to traditional doctrines is not supported by the ignorance of the results of the modern sciences" (Fröbes, 1911) and, in turn, "adherence to these sciences is not based on ignorance of the truths acquired by the philosophical tradition" (Fröbes, 1911). Fröbes cited positive examples of this dialogue between philosophy and science, the works of two authors: the neo-Thomist D. J. Mercier (1851-1926), author of Psychologie (1920); and the Jesuit Michael Maher (1860-1918), author of Psychology empirical and rational (1890/1902).

At the beginning of the treatise, when discussing the term psyche, Fröbes (1911) observed that it assumes different meanings and that there are some reductionist interpretations, such as that which eliminates the sensitive soul, or that which poses an opposition between the psychic and the physiological, possibly referring to the tradition of Cartesian derivation and of spiritualistic nature. Regarding psychic life, he understood this as the life that is aware of itself. The author differentiated between sensory life and intellectual life: with the latter performing operations such as reasoning, the choice of immaterial goods, being of the man and not of other animals.

The exposition of sensory psychology is divided into two parts: general or animal psychology, which deals with the study of animal sensory life; and "special psychology of the affective life", which concerns phenomena such as sensations, the operations of the inner senses (a term which, according to Massimi, 2012, refers, in the Aristotelian Thomistic tradition, to memory, to imagination and to the vis aestimativa), the cognitive and affective processes, motivation, activity and habit.

The text is written in Latin, which, as already mentioned, was the language used at the time in the institutions of the Catholic Church, however, the author curiously resorts to the use of the German language to deal with issues that were controversial, current and discordant to the tradition.

In these parts, Fröbes (1911) discusses theories of experimental psychology and science: Loeb's theses on tropism (Loeb, 1890); W. Wundt and his treatise on physiological psychology (Wundt, 1874); the discussions at the Fifth International Congress of Psychology held in Rome in 1905, with the presence of W. James (De Sanctis, 1906); and the theories of F. Galton (1869, 1883, 1889) and E. L. Thorndike (1904, 1905, 1911).

After the writing of the 1911 manuscript, between 1915 and 1920 Fröbes published a treatise on Experimental Psychology, written in German (Fröbes, 1917-1920), a compendium of speculative Psychology, written in Latin for school use (1927); and later a compendium of Experimental Psychology, also written in Latin (Fröbes, 1915/1937). The compendium was translated into different languages and used for teaching the discipline in several countries of the world (Fröbes, 1961). The first edition of the book, produced by an official institution of the Society in the Latin language, the official language of the Catholic Church, indicates the full acceptance of the area within the Society of Jesus.

In the compendium, the author distinguished 
between philosophical psychology (speculative, metaphysical) and experimental or empirical psychology. He wrote:

Psychology, as well as physics and the other sciences that have emerged from the bosom of philosophy, has gradually separated into two scientific branches, these being philosophical psychology and empirical psychology. Philosophical psychology (speculative, metaphysical) investigates, first of all, the more general questions which have always been of great interest to all mankind: these questions are the substantiality of the soul, the relationship between body and soul, the controversy regarding psychophysical parallelism, the freedom of the will and the immortality of the human soul. This does not mean that this psychology deduces its properties, a priori, from the essence of the soul, as some of the moderns affirm; on the contrary, it is based on the observation of acts and properties, to deduce from them the nature of their substantial substrate. (Fröbes, 1961, p. 7)

In suggesting this distinction, Fröbes seems to evoke the traditional classification of psychology into rational and experimental from the proposal of German philosophy in the eighteenth century. This classification contemplated the organization of psychology into two complementary areas: empirical or scientific psychology, which investigates psychic life in its relationships with physiology and bases its theories on data from experience; and rational or philosophical psychology, which is concerned with traditional issues of philosophical psychology (such as the origin and destiny of the soul, its nature, etc.), and uses deductive methods to draw conclusions. The formulation of this distinction is due to C. Wolff (1679-1754); later, I. Kant (1724-1804) took it up, denying, however, scientific value to both areas (Vidal, 2006). Throughout the nineteenth century, various approaches to philosophical psychology, such as the spiritualist and neo-Thomist approaches, have assumed this division, which also appears in the scholastic manuals of philosophy. In Brazil, for example, authors like Eduardo Ferreira
França (1809-1857), in Investigações de Psicologia (1854), José Soriano de Souza (1933-1895) in Compêndio de Filosofia, ordenado segundo os princípios e métodos do Doutor Angélico, S. Tomás de Aquino (1867) and Lições de filosofia elementar, racional e moral (1871) (Massimi 1990, 2004, 2016), used this classification. At the International Congress of Rome, mentioned earlier, the Italian philosopher F. De Sarlo presented a lecture called La psicologia in rapporto alle scienze filosofiche expressing the need for an intimate relationship between the two disciplines and evoked the two forms of being of psychology: philosophical and experimental (De Sarlo 1905).

In the teaching of the colleges of the Society of Jesus, the debate about the relationships between rational psychology and experimental or empirical psychology is evident. In documents gathered together in the Archives of the Society of Jesus in Rome, referring to the philosophical teaching at the Gregorian University, we find the introduction of experimental psychology together with the traditional rational psychology since the first decades of the twentieth century (MacSey, 1919; Monaco, 1919). An analogous insertion of psychology into the curricula of the Ignatian Colleges took place in other countries: for example in Spain (Guimerá, 1921). The mode of inclusion of scientific psychology into Jesuit studies, indicated by the documents, is in full conformity with the spirit of 'accommodation' to the contemporary cultural environment which, as we have seen, characterized the Order of Loyola from its origins. Just as in the sixteenth century, the Conimbrican philosophers sought to reconcile in their treatises the doctrines of the 'ancients' with those of the 'moderns', in the aftermath of this tradition, Jesuit thinkers of the twentieth century sought to continue this dialogue inherent in the missionary charism of the Ignatians, for example, highlighting the complementarity between rational psychology and experimental psychology. This process of accommodation did not occur, however, without ruptures and intense debates, according to the reading of another document referring to the German Province of the Society, elaborated 
by Ciran Grutt, which evidences the dissent between the teachers of experimental psychology and those of rational psychology, in the Society's educational institutions in that Province (Grutt, 1920).

In short, at the time, manuals and treatises generally employed terminologies and modalities of organization of the area based on the existence of these two complementary areas of psychology, rational psychology and empirical or experimental psychology. These areas were, in the majority of cases, included in the field of philosophy and its teaching.

However, unlike the aforementioned tradition which conceived rational psychology and empirical psychology as parts of philosophy, Fröbes, using the terms "philosophical psychology" and "experimental psychology", highlighted the diversity of the domains to which each of these areas of psychology belong: one being part of philosophy; and the other of the experimental sciences. He introduced a relevant epistemological transformation, from an (apparent) perspective of continuity.

Experimental psychology, also defined as empirical psychology, was the object of Fröbes' Compendium:

Empirical psychology (in the same way as experimental physics) takes the phenomena as its starting point, and proposes, first of all, to describe them, to order them and to establish specific and general laws, according to the rules of inductive logic; leaving the study of the ultimate questions about the activity and nature of substance to philosophy. (1961, p. 8)

Fröbes defined experimental psychology, from the methods used and reiterated that this is "the science which, through observation and experiment, investigates the psychic phenomena and their laws". He attributed an extensive domain to experimental psychology, which encompasses all "the internal facts that each one knows only through consciousness, such as thoughts, reflections, doubts, memories, feelings, affections, desires, decisions, and to put it into one word, the psychic facts, the conscious psychic phenomena, or the consciousness" (1961, p. 8).
Fröbes stated that psychology aims to describe and explain the phenomena and exemplified the statement by addressing the theme of affection and expressing total harmony with the Wundtian perspective (Freitas, 2010). Fröbes wrote: "to describe the affections means to reduce these phenomena by analyzing their simple elements, and to order the elementary facts". The explanation implies "indicating the causes of each psychic fact". He also discussed the topic of the sensation: explaining that a sensation is "to evidence the physical stimulation and its action in the central nervous system" (1961, p. 9). Here, without directly quoting him, Fröbes seems to have been inspired by the English psychologist E. B. Titchener (1908). For this author, the sensations were "conscious elementary processes, related to bodily processes in defined organs" (Titchener, 1899, p. 35), caused by the stimulation of peripheral organs and excitation of the central organ (Marcellos, 2012). However, in order to avoid accusations of reductionism, Fröbes observed that it was not a question of reducing the sensations to their physical conditions, as heat is reduced to the movements of the molecules; but to discern the causes of the psychic facts, that is, to recognize whether they are in the plane of the physiological domain, or of the purely psychological domain.

The discussion about psychological research methods is especially interesting: it shows the mode of appropriation employed by Fröbes, characterized by the mediation between the results of experimental science and the tradition of the knowledge of the Society. Fröbes cited, among the methods of experimental psychology, the introspective method, which is defined as self-observation, and the observation of the behavior of others. In addressing introspection, he states that "we practice it when we examine within ourselves the motives for a decision made, when we analyze our consciousness" (Fröbes 1961, p. 9). In this section, we see the attempt by Fröbes to approach introspection, a method particular to experimental psychology, and the examination of conscience proposed by Spiritual Exercises of Ignatius of Loyola, in particular in paragraph forty-three of the text ("How 
to take the general exam...”) (Loyola, 2002). From the Jesuit perspective, the examination of conscience is a detailed and careful analysis of one's inner experiences leading to discernment: a process by which the various levels of a particular experience are distinguished in order to clarify intentions, to separate what is mixed (and could confuse) and to evaluate the motives in a correct way, in order to make decisions (Jurado, 1997). In a particular way, the "discernment of the spirits" is applied to the specific field of states of mind, inner movements, tendencies, and inclinations. Knowledge of the self and entering into the self are, in the Ignatian view, the fundamental way to achieve the ordering of the soul life. Fröbes provided an argument to support his proposed association between Wundtian introspection and Ignatian self-analysis: "contemporary experimental psychology endeavors to assimilate everything that in ancient theories had a real value" (Fröbes, 1961, p. 15). At the same time, he was concerned to clarify that the introduction of the experimental method was a factor of innovation with respect to the past, because "it makes it possible for research work to be similar to the procedures that, for a long time, were used in physics and physiology, ensuring a secure and steady progress" (Fröbes, 1961, p. 15). The importance of the introspective method in the science of the psyche is due to the particular characteristic of the psychic facts, which, being facts of consciousness, "can only be seen on the internal side by those who experience them" (Fröbes, 1961, p. 19). Here Fröbes takes a position far removed from that of the founders of experimental psychology, W. Wundt and W. James (Abib, 2009): the need to consider psychic phenomena as an expression of the personal process. This position, in turn, supports the importance of philosophical psychology, which is concerned with investigating the nature of the person. Fröbes affirmed that

the characteristic of the whole psychic world is the personal character, that is, the fact that it is always attached to a 'self'. The unity of the self is not a functional union like that existing between the parts of a mechanism, but it is a nexus that unites all acts to the same and identical self. The feelings, the images, and the sensations are "my" feelings, "my" images and "my" sensations. (Fröbes, 1961, p. 19)

This concept evokes the doctrine about the person exposed by Augustine of Hippo in De Trinitate (Massimi, 2010). According to Augustine, the soul knows with certainty that it exists, lives and understands. This experiential "knowing" of the soul about itself does not only encompass the field of being and understanding, but also that of will and memory. The existence of a unitary and unique center of the human being, a subject conscious of his acts, is evidenced then in these terms: "I remember that I have memory, understanding, and will, I understand that I understand, will and remember, and I will that I will, remember and understand. At the same time, I remember my whole memory understanding and will" (Augustine, 416/1995, p. 331). At this point, Augustine introduced the concept of person:

I, by all these three things remember, I understand, I love, I, who am neither my memory, nor my understanding nor my love, but I have these. Such things could be said, therefore, by one person who has these three things and is not himself these three. (416/1995, p. 540)

In summary, it is clear that Fröbes carried out an appropriation of experimental psychology, seeking to reconcile it with the tradition of philosophical and theological knowledge about the person and his psyche, through an operation of accommodation that focused on the proximity aspects, placing the irreconcilable differences in the background.

When reconstructing the history of the phases of the development of psychology, the author clearly stated the importance of the introduction of the experimental method in Psychology, giving G. Fechner the merit for this step:

The founding of the new science was due to Fechner in his famous work Elemente der Psychophysik (1860), where he gathered an immense multitude of ancient and new facts related to the psychic life, established the psychological methods and made an inge- 
nious attempt to apply mathematical formulas to the magnitude of the intensity of the sensations. The principle of the measurement of the sensations was progressively abandoned, but the methods he provided were perfected theoretically and practically and are still applied today in the study of new questions. (Fröbes, 1961, p. 15)

Interestingly Fröbes, who, as we have seen, was a student of Wundt, attributed the role of founder of psychology to Fechner, through the "ingenious attempt" to apply mathematization to measure the intensity of sensations. At the same time, Fröbes criticized associationist psychology, because it was limited to the study of sensations "without recognizing the distinct essence of the thoughts and will" (Fröbes, 1961, p. 16). In this phrase Fröbes used a term from philosophical psychology, "essence", to qualify the cognitive and motivational phenomena that belong to the domain of experimental psychology. In addition to W. James (Bertoni \& Pinto, 2007), several of Fröbes' contemporary philosophers highlighted the failings of associationist psychology, among them Edith Stein (1922/1992). Fröbes commented that, because of the influence of associationist psychology on experimental psychology, "the sciences of the spirit did not recognize an adequate foundation in it and created a spiritual psychology" (1961, p. 16), through the contribution of W. Dilthey and E. Spranger. In fact, Wilhelm Dilthey (1833-1911) with his work Einleitung in die Geisteswissenschaften (1883/1948) sought to overcome this epistemological monism by proposing that, instead of the simple uncritical adoption of the methods of the Natural Sciences, an adequate methodology should be constructed for the human sphere and its products. He called this sphere the Sciences of the Spirit (Geist), denoting, by the use of the term, the exclusive qualitative aspect of the human personal structure, circumscribed not only at the individual level, but also at the social level.

Eduard Spranger (1882-1963), a lecturer at the universities of Leipzig, Tübingen and Berlin, devoted himself mainly to the study of the personality and education. His work of 1914, Lebensformen: Geisteswissenschaftliche Psycholo- gie und Ethik drr Personlichkeit, was published in English in 1928 (Spranger, 1928; Young, 1942), however, evidently Fröbes was already aware of his positions and research. Spranger, like Dilthey, defended psychology as a science of the spirit, the object of which was the man in his relationships with culture and society.

It is interesting to note that Fröbes, despite acknowledging the contribution of these authors, did not take the lead in defending the relevance of the sciences of the spirit, but proposed the amplification of the area of experimental psychology. Indeed, in his text he observed that, following the criticisms of Dilthey and Spranger, experimental psychology extended its field to the more complex regions of psychic life, so that "we can now find in experimental psychology established with a base in the scientific method, that which was previously treated in the context of spiritual psychology" (Fröbes, 1961, p. 17). From this he followed that "experimental psychology is the foundation of all the sciences of the spirit" (Fröbes, 1961, p. 17). The defense of the importance and prominence of experimental psychology was based on the fact that it was not only limited to the study of sensations but had "gradually spread to the higher regions of psychic life" (Fröbes, 1961, p. 17).

This position was shared by several authors of the time, especially in the German context, among them Wundt himself (Araujo, 2016). It was, however, questioned by others, being labeled psychologism in the wake of Husserl's criticism (Porta, 2010). Stein also criticized psychologism in Psychische Kausalität. Beiträge zur philosophischen Begründung der Psychologie und der Geisteswissenschaften, Erste Abhandlung. Jahrbuch für Philosophie und phänomenologische Forschung (1922/1992), her habilitational thesis produced to obtain an academic chair in philosophy in Gottingen in 1919.

Fröbes' construction of arguments shows that the appropriation of experimental psychology in the form of the Society's knowledge was not made so much in the merits of epistemological questions, as Dilthey, Spranger, Husserl and Stein did, but in the process of accommodation which we have described above and which seeks 
to highlight the similarities between scientific knowledge and traditional knowledge. However, Fröbes' choice of experimental psychology for scientific supremacy (whether methodological or of content) is clear.

The Compendio de Psicologia Experimental written by Fröbes had several editions from the first of 1915 (Fröbes, 1920, 1922, 1923, 1929, 1935, 1937, 1941). Among them, one, already mentioned, was published by the Gregorian University, an institution of the Society of Jesus, in 1937. This fact shows that within the Society, at that moment, the importance of Experimental Psychology was definitively recognized.

The contribution of the Jesuit J. Fröbes to psychology has been highlighted by several historians of psychology (Misiak \& Staudt, 1954); His autobiography appears in the third volume of the monumental work organized by Murchison, A History of Psychology in Autobiography (1936). This fact confirms the prominent role played by Fröbes in the field of psychology, a role widely recognized by the scientific community. In Murchison's third volume, Fröbes is placed in the group of the most important German psychologists; and with the Americans James Rowland Angell, Madison Bentley, Harvey A. Carr, Edward Wheeler Scripture, Edward Lee Thorndike, John Broadus Watson.

In the autobiography, Fröbes structured his intellectual life in three large blocks: his life experience as preparation for scientific work; his performance as an experimental psychologist; and his work in the area of philosophical psychology. He reported on his formation at the Jesuit college of Feldkirch in Austria and said that period was the best of his life, having experienced the fact that "the religious experience permeated his whole life", giving him motivation and enthusiasm (Murchison, 1936, p. 122). This experience, together with the admiration of the teachers of the college and the desire to imitate them, led him to the priestly vocation in the Society of Jesus; and he stated that, throughout the fifty years of life in this situation, he never regretted the decision. The report of the humanistic formation received in the novitiate was quite detailed, specifically regarding the philosophical studies marked by scholastic philosophy. His propensity for studies in physics and mathematics, stimulated by some brilliant teachers, encouraged him to follow the path of science. He narrated that, after finishing his training, when he was a professor, he casually read a book on experimental psychology by W. Wundt, recognizing it as the best way to cultivate his aptitude for science while, at the same time, dealing with the human experience. He then asked the superiors for permission to suspend his teaching activities for two years to conduct research in a laboratory of experimental psychology. With this aim, he went to the University of Gottingen between 1902 and 1904, where he developed experimental activities in the field of psychophysics under the guidance of George Elias Müller. At this university he also attended psychiatry classes and some courses with E. Husserl. In the final period of his leave, he went to Leipzig, considered the "cradle of the new psychology" (p. 129), taking classes with Wundt and attending his laboratory. In the two years that followed, once he returned to teaching activities, he attempted to integrate his studies in order to construct a panorama of all the fields of psychology, both experimental and philosophical. He reported that, for this purpose, he undertook the task of writing two manuals, one of experimental psychology (the first edition in 1905 and the second much more extensive edition between 1908 and 1910); and one of philosophical psychology, in 1920. Regarding these treatises, also translated into the English and Spanish languages, presented earlier, Fröbes commented that they sought to clarify the difference between the two areas in areas and methods: experimental psychology performs empirical and experimental studies in terms of positive science, omitting any philosophical reasoning; with the metaphysical questions not constituting premises for scientific psychology. Philosophical psychology is not antithetic to experimental psychology and Fröbes' goal was to "reconcile old and new psychology" (Murchison, 1936, p. 143), also taking into account the important contributions of this area for pedagogy. His autobiographical narrative ends with the declaration of the purpose of constructing an adequate philo- 
sophical foundation for scientific psychology, in continuity with the scholastic tradition. Although he was unable to achieve his aim, the relevance of Fröbes, as stated by Misiak and Staudt (1954), was to assume, in Germany, as well as D. Mercier in Belgium, the role of integrating psychology into the Catholic world with experimental psychology (vetera cum novis coniungere). The two historians highlighted the important role played by the Compendium of Experimental Psychology, by espousing the universal acceptance of this area as a separate and independent science, encouraging Catholics to study it.

Fröbes's treatises and teaching activity inspired young people to be enthusiastic about the area: one of his students, Johannes Lindworsky, followed him on this path, becoming in turn devoted to the integration of experimental psychology and philosophy.

\section{Johannes Lindworsky and the Experimental Study of the Will}

Johannes Lindworsky (1875-1939) had a rich and diverse scientific and philosophical background: he obtained a doctorate in Munich under the supervision of J. Fröbes, was a professor in Prague in 1928 and then in Rome at the Gregorian University. He was sympathetic to the school of Würzburg and to the research developed there on thought without images, however, mainly studied the concept of will and motivation. Rozestraten (2004) states that, as a teacher in Cologne, he continued the work of Kulpe and the Würzburg school. He wrote several treatises in the field of psychology that were translated into several languages and widely disseminated (OCLC Online Computer Library Center, 2010). Among them are: Der Wille (1919) and Willenshulke (1922), where the author used experimental laboratory data to refute the traditional doctrine of will as a force and proposed a new theory based on the concept of motivation. Der Wille had 33 editions published in Germany between 1921 and 1923; and 19 editions in other languages between 1923 and 1986. Willenshulke had 26 editions in Germany between 1922 and 1953; and 18 editions in other languages between 1926 and 1961. Lindworsky also published Psychologie der Aszese: Winke für eine psychologisch richtige Aszese (1935/1946), which was translated immediately into several languages, having eighteen editions published between 1935 and 1948; Experimental Psychology (1921/1939); and Theoretical Psychology (1932). The treatise on Experimental Psychology had 112 editions published in various languages between 1921 and 2016; that of Theoretical Psychology had 23 editions between 1932 and 2011. In short, Lindworsky's texts played a significant role in the transmission of psychological knowledge in the world.

Similar to J. Fröbes, the production of Lindworsky seems to exemplify the disposition to accommodation and the mode of appropriation of knowledge of the spirit of the Society: in a religious text dedicated to the psychology of asceticism, he states that spirituality can be supported by results and guidance stemming from advances in scientific psychology. Thus, recourse to the science of the psyche can help the spiritual formation to form authentic and integral men (Lindworsky, 1935/1946).

When teaching philosophy in Prague, he published Experimentelle Psychologie (1921/1939), a manual that was translated into several languages. In this text, Lindworsky stated that "the methods of experimental psychology conform to the nature of its sources. As consciousness is the primary source, it follows logically that introspection is the primary method" $(1921 / 1939$, p. 10). Concerning introspection, Lindworsky highlighted that "the primary scientific method of experimental science is retrospective selfobservation; but since occasional introspection is not sufficiently comprehensive to build up a whole new science, the technique has been subjected to a systematic study". He also defined the essence of the experiment, as "the voluntary direction of mental processes for the purpose of scientific observation" (p. 11). In this way, this author, as well as Fröbes, in associating the introspective practice which, as we have seen, was diffused in the Society from the Spiritual exercises of Ignatius of Loyola, to the experimental introspection of the Wundian matrix, 
performs an accommodation operation between two traditions very distant from each other and an appropriation of experimental psychology into the molds of the Jesuit vision.

In the previously cited works of Der Wille (1919) and Willenschule (1922) about the will, Lindworsky used experimental data to establish the primacy of motivation as the key to the will. For these studies he used a method of systematic introspection, already discussed in the eighth section of the first volume of the treatise on Experimental Psychology: starting from the studies of A. Michotte (1962), he describes the experience of volition as an act in the present, in the first person, always having some purpose and manifesting different intensities. The results of Lindworskys studies demonstrate that the capacity of will may be different among individuals: some have more willpower; others, less. However, if we consider willpower as the energy of a content of consciousness, of a set of values and ends, this implies that there are sets of values (motives) that can totally mobilize the will, and others that partially succeed. Lindworsky's conclusion was that educating the will means proposing comprehensive and totalizing purposes that can capture the energy of young people in all the spheres of life. The focus on the subject of the will is dear to the Society of Jesus: among the most important productions on this theme, we recall the De arte voluntatis, libri sex: in quibus Platonicae, Stoicae, \& Christianae disciplinae medulla digeritur, succo omni politioris Philosophiae expresso ex Platone, Seneca, Epicteto, Dione Chrysostomo, Plotino, Iamblicho, \& alÿs: quorum sensa subtiliora artificiosiùs ordinantur; nonnulla emendantur, plurima adauntur nove, \& argute (doravante DAV); written in 1631 by the Jesuit J. E. Nieremberg, dedicated to the education of the will and based on the concept that will depends on the objects of cognition (Pacheco, 2014a, 2014b). Thus the concept of the will that inspired Lindworsky's experimental studies is in accordance with the Jesuit tradition of Aristotelian-Thomist matrix that established a strong link between this psychic process and cognition. Values and ends, with effects, are objects of cognition. Again, we are faced with a form of appropriation that seeks to reconcile tradition and modernity: the verification of a traditional matrix theory, through experimental methods.

Lindworsky's writings were widely disseminated in Europe and the Americas, especially those of the area of education. His attempt to integrate philosophical and experimental psychology was not performed from an epistemological perspective, but from the fact that he used experimental data to construct theories about psychological phenomena. Thus, in the studies regarding will, for example, he integrated experimentation and philosophical concept; taking care to affirm that experimental studies cannot directly prove the existence of freedom, however, they can show its effects. Brennan (1969) also highlighted the importance of Lindworsky in explaining attention as a result of the joint activity of will and cognitive processes.

\section{Conclusion}

The contributions to psychology in the first decades of the twentieth century by the Jesuit authors analyzed here show the importance that scientific psychology assumed in the thought and performance of the Society of Jesus and its particular modality of appropriation, making the inherited cultural tradition compatible with the novelties of contemporary science. Thus, the philosophical psychology of the Thomist matrix interpreted according to the general philosophical orientation of Catholic thought of the time was presented in its complementarity with the newly created experimental psychology. The view of man and of psychic processes based on tradition was verified and discussed from the methods and themes of the science of the contemporary world. In this sense, the contrast between rational psychology and experimental psychology, derived from German philosophy, was reinterpreted in the Jesuit context in terms of complementarity, making dialogue possible between the ancient and the modern, which, as we have seen, was advocated by the charism of the Society since its origins.

It should also be noted that although the Je- 
suits adhered to the use of experimental methods in psychology, they nevertheless maintained their preference for the study of themes especially significant in the tradition of the Society, such as that of will.

In a historical context marked by the rupture between psychological knowledge of the tradition and new knowledge derived from scientific advances, Fröbes and Lindworsky carried out a search for a continuity achieved in a dynamic way. They evidenced possibilities of interpreting, in the light of tradition, the results obtained by experimentation and introduced new uses for psychology and its resources, focused on intervention (for example, in the educational field) and experimentation. For example, the method of experimental introspection, appropriated by the two Jesuit authors to bring it closer to the practice of self-examination and discernment, was used and diffused by them through their lessons and, above all, their treatises. At the same time, both authors argued that the results of experimentation should be applied in areas traditionally reserved for the areas of spirituality and philosophy. The aforementioned motto vetera cum novis coniungere synthesizes the particular mode of appropriation of these authors, shaped by their belonging to the intellectual tradition of the Society of Jesus, but also by their insertion within the cultural and scientific universe of their time, from which they seem to seek to reinterpret, in a new way, concepts and methods of the tradition.

\section{References}

Abib, J. A. D. (2009). Epistemologia pluralizada e história da psicologia. Scientiae Studia, 7(2), 195-208

Augustine. (1995). Sobre a Trindade (A. Belmonte, Trans.). São Paulo, SP: Paulus. (Original work in 416).

Araujo, S. F. (2016). Wundt and the Philosophical Foundations of Psychology: A Reappraisal. New York: Springer.

Bertoni, P. G., \& Pinto, D. C. M. (2007). Mudança e continuidade: A formação Jamesiana do pensamento como um fluxo. Psicologia: Reflexão e Crítica, 20(2), 205-211.
Brennan, R. E. (1969). Psicología general (A. L. Maza, Trans., $2^{\text {nd }}$ ed.). Madrid: Morata.

Caeiro, F. G. (1982). O pensamento filosófico do século XVI ao século XVIII. In Portugal e no Brasil, Acta do l Congresso Luso-Brasileiro de Filosofia (pp. 51-90). Braga, Portugal: Universidade Católica.

Chartier, R. (1991). O mundo como representação. Estudos Avançados, 11(5), 173-189.

Chinchilla, P., \& Romano, A. (Eds.). (2008). Escrituras de la modernidad. Los jesuitas entre cultura retorica y cultura cientifica. Ciudad de Mexico, DF: Universidad Iberoamericana-Ehess.

Colombo, E., \& Massimi, M. (2014). Gesuiti candidati alle missioni tra Antica e Nuova Compagnia. Il Sole 24 Ore (Milano), viaggio.

De Sanctis, S. (1906). Atti del Quinto Congresso Internazionale di Psicologia tenuto in Roma dal 26 al 30 aprile 1905 sotto la presidenza di Giuseppe Sergi. Rome: Forzani Tipografia del Senato.

De Sarlo, F. (1905). Lo spiritualismo al Congresso di Psicologia. Studi Religiosi. Rivista Critca e Storica Pormotrice della Cultura Religiosa in Italia, 5, 257-269.

Dilthey, W. (1948). Introducción a las ciencias del espiritu. Buenos Aires: Espasa-Calpe. (Original work published 1883)

Freitas, S. A. (2010). O projeto de uma psicologia cientifica em $W$. Wundt. Juiz de Fora, MG: Editrice Università Federale.

Frielingsdorf, K. (2001). J. Fröbes. In C. E. O’Neil \& J. M. Dominguez, Diccionario Histórico de la Compañia de Jesús (Vol. II, p. 1534). Rome: Institutum Historicum S.I.

Fröbes, J.(1911). Psychologia Sensitiva [Manuscript]. Archivum Romanum Societatis Iesu (ARSI, Segnatura: OPP. NN. 1028). Valkenburg, Holland.

Fröbes, J. (1917-1920). Lehrbuch der experimentellen Psychologie (Vols. 1-2). Freiburg, Germany: Herder.

Fröbes, J. (1927). Psychologia speculativa in usum scholarum. Freiburg, Germany: Herder.

Fröbes, J. (1937). Compendium Psychologiae Experimentalis. Rome: Università Gregoriana. (Original work published 1915) 
Fröbes, J. (1961). Compendio de Psicologia Experimental (J. A. Menchaca, Trans., $5^{\text {th }}$ ed.). Madri: Razón y Fe.

Galton, F. (1869). Hereditary Genius. London: Macmillan.

Galton, F (1883). Inquiries into Human Faculty and Its Development. London: J. M. Dent \& Company.

Galton, F. (1889). Natural Inheritance. London: Macmillan.

Giard, L. (1995). Les jésuites á la Renaissance. Système éducatif et production du savoir. Paris: Presses Universitaires de France.

Gibert, P. (2006). Universitas Nostra Gregoriana. La Pontificia Università Gregoriana ieri e oggi. Rome: Pontifícia Universidade Gregoriana.

Grutt, C. (1920). De studio Psychologiae experimentalis et de eius habitudine ad Psychologiam rationalem. Archivum Romanum Societatis Iesu (ARSI, n. 32 de 1920 da Pasta Província alemã). Rome.

Guimerá, V. (1921). Informacion de P. Vicente Guimerá. Archivum Romanum Societatis Iesu (ARSI, Algunos apuntes sobre el estudio de ciencias em la Provincia de Aragon 1920-21, Roma, 7 dez. 1921.) Rome.

Jurado, M. R. (1997). Il discernimento spirituale. Cinisello Balsamo, Italy: San Paulo.

Lindworsky, J. (1919). Der wille, seine erscheinung und seine beherrschung, nach den ergebnissen der experimentellen forschung. Leipzig, Grmany: J.A. Bart.

Lindworsky, J. (1922).Willensshule. Padherborns, Germany: Schöning.

Lindworsky, J. (1932). Theoretical Psychology. London: B. Herder Book.

Lindworsky, J. (1939). Manuale di Psicologia sperimentale (E. Galli, Trans.). Milão, Italy: Gatti. (Original work published 1921)

Lindworsky, J. (1946). Psicologia de la ascetica (G. Del Valle, Trans.). Buenos Aires: Excelsa. (Original work published 1935)

Loeb, J (1890). Der Heliotropismus der Thiere und seine Uebereinstimmung mit dem heliotropismus der Pflanzen. Würzburgo, Germany: Verlag von Georg Hertz.
Loyola, I. (2002). Exercícios Espirituais. São Paulo, SP: Edições Loyola.

Macsey, C. (1919). Responsa ad quaesita posita in consultatione de studiis universitate Gregoriana. Archivum Romanum Societatis Iesu (ARSI, Studia 41020 Doc. 1911-19). Rome.

Maher, M. S. I. (1902). Psychology. Longan, UT: Green. (Original work published 1890)

Marcellos, C. F. (2012). Objeto e método na Psicologia de Wilhelm Wundt e Edward Titchener: Um estudo comparativo (Master's thesis, Universidade Federal de Juiz de Fora, MG, Brazil).

Massimi, M. (1990). História da Psicologia brasileira. Da época colonial até 1934. São Paulo, SP: Editora Pedagógica Universitária.

Massimi, M. (2004). História da Psicologia no Brasil do século $X X$. São Paulo, SP: Editora Pedagógica Universitária.

Massimi, M. (2010). A pessoa e o seu conhecimento: Algumas etapas significativas de um percurso conceitual. Memorandum, 18, 10-26. Retreived from http://www.fafich.ufmg.br/ memorandum/ a18

Massimi, M. (2012). Imaginação e imagens: Conceitos e práticas em tradições culturais da modernidade ocidental e do Brasil colonial. Memorandum, 23, 158-184. Retrieved from http://www. fafich.ufmg.br/memorandum/a23/massimi06

Massimi, M. (2016). Saberes psicológicos no Brasil. Curitiba, PR: Juruá.

Massimi, M., \& Freitas, G. R. (2007). Acomodação retórica e adaptação psicológica na pregação popular dos jesuitas na Terra de Santa Cruz. Mnemosine, 3(1), 111-135.

Mercier, D. F.F. J. (1920). Psychologie. Louvain, Belgium: Institut Supérieur de Philosophie.

Michotte, A. (1962). The perception of causality. Andover, MA: Methuen.

Misiak, H., \& Staudt, V. (1954). Joseph Fröbes. Catholics in psychology: A historical survey. (pp. 84-97). New York: McGraw-Hill Book. doi:http://dx.doi.org/10.1037/11143-006.

Monaco, N. (1919). Risposte ai due quisiti proposti dal P. Rettore a nome del MRP Generale riguardo al modo d'istituire un corso superiore di teologia e filosofia all'Universitá Gregoriana. Archivum Romanum Societatis Iesu (ARSI, 
Studia 41020 Doc. 1911-19, Roma 16 de maio de 1919). Rome.

Murchison, C. A. (Ed.). (1936). History of Psychology in Autobiography: Vol. 3 (pp. 121-147). Worcester, MA: Clark University Press.

OCLC Online Computer Library Center. (2010). OCLC WorldCats Identities: Lindworsky, Johannes 1875-1939. Retrieved from http://www. worldcat.org/identities/lccn-n2003-32612/

Pacheco, P. R. A. (2014a). O segundo livro do tratado De Arte Voluntatis de Juan Eusebio Nieremberg (1595-1658). IHS. Antiguos Jesuitas en Iberoamérica, 2(1), 121-194.

Pacheco, P. R. A. (2014b). O terceiro livro do tratado De Arte Voluntatis de Juan Eusébio Nieremberg (1595-1658). IHS. Antiguos Jesuitas en Iberoamérica, 2(2), 150-221.

Porta, M. A. G. (2010). Husserl: fenomenologia, psicologismo, psicologia. São Paulo, SP: Loyola.

Romano, A. (1999). La contre-réforme mathématique. Constitution et diffusion d'un culture mathématique jésuite à la Renaissance (15401640) (Coll. Bibliothèque des Écoles françaises d'Athènes et de Rome, 306). Rome: École Française de Rome

Romano, A. (2012). Jésuites et science moderne. Les voies européennes et non-européennes d'un engendrement conflictuel. In V. Jullien, E. Nicolaidis, \& M. Blay (Eds.), Europe et sciences modernes. Histoire d'un engendrement mutuel (pp. 273-296). New York: Peter Lang.

Rozestraten, R. J. A. (2004). As tentativas dos cognitivistas pioneiros. Estudos de Psicologia (Natal), 9(1), 5-15. doi:http://dx.doi.org/10.1590/ S1413-294X2004000100002

Spranger, E. (1928). Types of men: The psychology and ethics of personality (T. Pigors, Trans.). Halle, Germany: Max Niemeyer.
Stein, E, (1992). Beiträge zur philosophischen Begründung der Psychologie und der Geisteswissenschaften. In M. Niemeyer (Ed.), Jahrbuch für Philosophie und phänomenologische Forschung (Vol. 5). Halle, Germany. (Original work published 1922)

Thorndike, E. L. (1904). Introduction to the Theory of Mental and Social Measurements. New York: The Sciences Press.

Thorndike, E. L. (1905). The Elements of Psychology. New York: Seiler.

Thorndike, E. L. (1911). Animal Intelligence. New York: The Macmillan Company.

Titchener, E. B. (1899). An Outline of Psychology (3 $3^{\text {rd }}$ ed.). New York: The Macmillan.

Titchener, E. B. (1908). Elementary Psychology of Feeling and Attention. New York: The Macmillan.

Vidal, F. (2006). Les Sciences de l'âme XVI-XVIII siècle. Paris: Champion.

Wundt, W. (1874). Grundzuge der physiologischen Psychologie. Leipzig, Germany: Engelmann.

Young, A. W. (1942). A study of the dominance of six basic motives in personality as set forth by Eduard Spranger in his book, "Types of Men". ETD Collection for AUC Robert W. Woodruff Library (Paper 404).

(C) The Author(s), 2018. Open Access. This article is distributed under the terms of the Creative Commons Attribution 4.0 International License (http://creativecommons.org/licenses/by/4.0/), which permits unrestricted use, distribution, and reproduction in any medium, provided you give appropriate credit to the original author(s) and the source, provide a link to the Creative Commons license, and indicate if changes were made.

Received: 27/10/2016

$1^{\text {st }}$ revision: $17 / 03 / 2017$

Accepted: 21/03/2017 